\title{
A moldáv identitás rétegei
}

\section{The layers of Moldavian identity}

\section{ILLÉS TAMÁS, BOTTLIK ZSOLT}

ILLÉS Tamás: doktorandusz, Eötvös Loránd Tudományegyetem, Természettudományi Kar, Földrajz- és Földtudományi Intézet, Regionális Tudományi Tanszék; 1117 Budapest, Pázmány Péter sétány 1/C.; tamas.illes92@gmail.com; https://orcid.org/0000-0001-5318-8375 BOTTLIK Zsolt: egyetemi docens, Eötvös Loránd Tudományegyetem, Természettudományi Kar, Földrajz- és Földtudományi Intézet, Regionális Tudományi Tanszék; 1117 Budapest, Pázmány Péter sétány 1/C.; agria@gmx.net; https://orcid.org/0000-0003-0337-5580

KULCSSZAVAK: nemzeti identitás; Moldova; nacionalizmus; posztszocializmus; posztszovjet

ABSZTRAKT: Tanulmányunkban a geopolitikai pufferzónában lévő moldáv népcsoport identitásának kialakulását vesszük górcső alá. A mai moldovai öndefiníció helyi tényezője a lakosság rurális karaktere, valamint a lassú urbanizációval kiéleződő város-vidék kettősség. Rámutatunk a moldáv etnikai tér városainak a 19. századtól folyamatosan kialakuló eltéréseire, amely a térség lakóinak identitásában jelenleg is a hely szerepét erősíti. Ennek további jellegzetességeként a két világháború közötti román centralizációs törekvések vidéki lakosság oldaláról történő elutasításának körülményeit, valamint a szovjet időszak város-vidék egyenlőtlenségének fennmaradását, illetve további elmélyülését fejtjük ki. A moldáv identitás megítélése regionális nézőpontból is eltéréseket mutat. A történelem során a politikai csatározások középpontjába állított területi viták, a migráció, a betelepítések a mai ország területén kulturális különbségeket, egzisztenciális és ezáltal társadalmi törésvonalakat hoztak létre. A jelenleg autonóm státuszt élvező Gagauziában, valamint a szakadár Transznyisztriában eltérő módon ítélték és ítélik meg a moldovai identitás kialakulását/kialakítását és a csoport románsághoz füződő viszonyát.

A moldáv nemzeti identitás ilyen előzmények után rendkívül rétegzett, így a moldáv nacionalizmusok egy átfogó keretrendszer helyett számos olyan, időben és térben összefonódó konstrukcióból táplálkoztak a helyhez kötődő, premodern elemek mellett, mint a modernizáció, az elitek projektje, valamint az ellenállás és a kirekesztés nyomán létrejött önvédelmi mechanizmusok. Ezek mellett jelenik meg a nemzeti projekt kulcselemeként a nyelv.

A nacionalizmusok - az ország geopolitikai pufferzónajellege miatt - távoli hatalmi centrumok igényei szerint alakultak, amely jelen tanulmányunkban a posztkoloniális kritikai szempontok érvényesítését támasztja alá. A globalizáció a nemzetépítést is kihívás elé állítja, amelynek során a lokális, regionális, nemzeti és a már globális kulturális javak megjelenését magában hordozó szupranacionális léptékek keveredését látjuk, és egyúttal a moldáv nemzeti identitás fluid és dinamikusan változó jellegét tapasztalhatjuk.

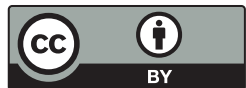


Tamás ILLÉS: PhD student, Department of Regional Science, Institute of Geography and Earth Sciences, Faculty of Science, Eötvös Loránd University; Pázmány Péter sétány 1/C., H-1117 Budapest, Hungary; tamas.illes92@gmail.com; https://orcid.org/0000-0001-5318-8375

Zsolt BOTTLIK: associate professor, Department of Regional Science, Institute of Geography and Earth Sciences, Faculty of Science, Eötvös Loránd University; Pázmány Péter sétány 1/C., H-1117 Budapest, Hungary; agria@gmx.net; https://orcid.org/0000-0003-0337-5580

KEYWORDS: national identity; Moldova; nationalism; post-socialism; post-Soviet

ABSTRACT: The theoretical framework of this study into the contested identity of the Moldavian population follows postcolonial approaches for a post-Soviet context. It tries to avoid naturalising differences and moves beyond still relevant structuralist and essentialist positions. Instead of biased hegemonic Western formulae and assumptions derived from Cold War dichotomies, our examination employs post-socialist points of view to shine a light on the complex imbrications of the Moldavian layers of identity. The paper is conceptually rooted in scales of analysis, ranging from local to supranational. But the hybrid, complex and fractured traits of the Moldavian identity cannot be reduced to a constructivist logic, hence differentiation of characteristics by scales is the heuristic tool of choice.

As our study points out, from a local point of view and for the purpose of today's Moldavian self-definition, the rural character of the population and the intensifying urban-rural splits were the most significant. The still-evolving differences between Moldovan urban spaces are reminders of the relevance of geographical place. Further characteristics refer to the peculiar circumstances of resisting Romanian centralisation endeavours especially by rural (allegedly Romanian) inhabitants, and the conservation (or even deepening) of urban-rural inequalities of the Soviet era. The assessment of the Moldavian identity differs also according to region. Political debates on the Moldavian territory are far from over, resulting in either enhanced migration or forced expulsions that created cultural cleavages and existential and social dividing lines. Not surprisingly, in now autonomous Gagauzia and separatist Transnistria, the emergence of a Moldavian identity and a rapprochement with Romania are still not unequivocal.

Therefore, the Moldavian identity is so inextricably intertwined in time and space that instead of a singular and overarching frame of a putative Moldavian nationalism, multiple nationalisms were at stake, influenced altogether by premodern elements, projects of elites and modernity, and self-defence mechanisms against exclusion and opposition. Language issues, too, have played a significant role in nation-building projects. In addition, a permanent geopolitical buffer zone stretches along the Republic of Moldova as nationalist sentiments have been stoked by the interests of remote centres of power. Globalisation also affects identities in multiple ways. As sub- and supranational level feelings are gathering momentum, nation-building projects face challenging obstacles. In conclusion, a blend of scales of analysis featuring local, regional national and even global cultural flows argue for a fluid and dynamic conceptualisation of the Moldavian national identity.

\section{Bevezetés}

A mai Moldovai Köztársaság a történeti Moldova keleti területét, természetföldrajzilag pedig lényegében a Dnyeszter, a Prut és az Al-Duna közötti területet foglalja magába. Az ország már a középkortól része annak az átmeneti geopolitikai zónának, amely a jelenleg köztes-európainak definiált térség és az orosz hatalmi érdekek között húzódik (Bochmann et al. 2012; Cazacu 1996). A területen a politikai csatározások mellett erőteljes volt a különböző nyelvek, feleke- 
zetek keveredése, ami mögött sokszor nagyon komoly történeti, társadalmi törésvonalak rejlenek, és amelyek a mai napig is sok esetben politikai színezetet kapnak. E problémákat leginkább a pufferzónajelleg határozza meg (Hofbauer, Roman 1997).

A moldáv lakosság csoportidentitását a kora középkorban kialakult Moldovai Fejedelemség állami keretei és az ország történelmi kataklizmái alapozták meg, később a nyelvi különállás jelölte ki, majd pedig a modern nacionalizmusok idején a hatalom nyelvpolitikája, ezzel párhuzamosan pedig az elitek geopolitikai mozgástere határozta meg. A modern nemzetté válás idején, az oszmán struktúrák lebontásával egyidőben a 19. századi, kezdetben orosz, később szovjet hatalmi expanzió és ezzel párhuzamosan a román nemzetépítés hatásai együttesen alakították ki az ország keleti újlatin nyelvet beszélő lakói körében a jelenleg megfigyelhető identitáskonstrukciókat (Neukirch 1996).

Alábbi tanulmányunk fő kérdése az, hogy a vizsgált térségben a társadalomban kialakult identitáskonstrukciók milyen elemekből építkeztek, illetve milyen elemeket hangsúlyoztak kívülről a térséget hatalmi érdekszférájukba illeszteni szándékozó nagyhatalmak. Megvizsgáljuk azt, hogy milyen dimenziói voltak az itt megjelenő nacionalizmusoknak (itt elsősorban a birodalmi jellegü, orosz, majd szovjet nacionalizmusra, valamint a tágabb térség keleti újlatin nyelvet beszélő csoportjait integrálni szándékozó román nacionalizmusra kell gondolni). Megvizsgáljuk továbbá, hogy milyen geopolitikai események hatottak az identitásokra, illetve milyen szerepet játszott ezekben a földrajzi és társadalmi hely. Összességében tehát a moldáv identitás „rétegeit” vesszük górcső alá.

\section{Elméleti keretek}

\section{A posztszovjet térség helyi sajátoságainak nyugati értelmezési kerete}

Az, hogy manapság egyáltalán a moldáv identitás rétegeiről beszélhetünk, szélesebb spektrumú változásoknak köszönhető, ugyanis a három világ metaföldraj$z a$, illetve a hidegháború geopolitikai diskurzusai eltakarták a periféria egyenlőtlen földrajzi viszonyait, ami a posztszovjet térség nemzeti identitásainak leegyszerüsítéséhez is vezetett. Az Európa keleti feléhez aggatott leegyszerüsítő képzetek természetesen nem kizárólag a hidegháború időszakának termékei, hanem már a felvilágosodás korában is a „köztes másság” (nem teljesen civilizált, nem teljesen barbár) metaforáival telítődtek (Wolff 1994). Ugyanakkor szovjet részről is kitapintható volt az identitások esszencializálása azáltal, hogy a kedvezményezett (pl. nem muszlim) etnikumok nemzeti intézményesülését erőteljesen támogatták, az állami vezetés ellenőrzésével. A Szovjetunió lebomlásával látszólag új megvilágítás alá kerültek a térség identitásai, de az ezek 
tanulmányozásához való viszonyunkat máig jelentős viták és szükre szabott elméleti keretek szegélyezik.

Hogyan jelenik meg a tudományos tudás termelésében és közvetítésében az európai posztszovjet térség, és azon belül a Moldovai Köztársaság? A jellemzően nyugati dominanciájú társadalomföldrajzi szakirodalomban - a korábbi évtizedek episztemológiai újításai ellenére - továbbra is egy jól körvonalazható tendencia makacs kitartása érvényesül, amely a helyi társadalmi kontextusokra érzéketlenül alkalmazott univerzalista alapvetésekben köszön vissza (Robinson 2003). Berg (2004) szerint a Nyugaton kívüli elméleteknek nincs magyarázó erejük, míg a nyugatiak nagyobb eséllyel cirkulálnak helyhez való kötöttség nélkül. Timár (2006) tanulmányában fájlalóan tesz utalást arra, hogy a nyugati kollégák elméleteiket az itteni jelenségekre alkalmazva hogyan váltak egyik napról a másikra a posztszocializmus szakértőjévé, így a helyi vizsgálatok a „nyugati (alapvetően angol-amerikai) elmélet - keleti empíria" egyenlőtlen felállású forgatókönyvei alapján készültek, és készülnek ma is.

Az európai posztszovjet társadalmi folyamatok elméleti kereteként leggyakrabban a posztszocializmus szolgál, azonban a nyugati nézőpontok a posztszocializmust teleologikus folyamatként a demokratizálódás és európaizálódás folyamatával azonosítják (Stenning, Hörschelmann 2008). A hiperglobalista álláspontra hajlamos globalizációs diskurzusok többsége is a „történelem végét” (lásd pl. Fukuyama 2014), a keleti országok átmeneti állapotát és „nyugatiasodását” érzékeltették (Illés 2018a). Nem véletlen, hogy az 1990-es évek térséggel foglalkozó társadalomföldrajzában a tranzitológiai paradigma (elsősorban gazdasági értelemben) alighanem egyeduralkodónak számított (Dingsdale 1999). Ám a Nyugat a priori alkotott fogalmaival, de még az olyan szavak, mint a peresztrojka vagy glasznoszty kontextus nélküli használatával sem lehetséges leírni, nemhogy hitelesen elemezni a kelet-európai országok átmeneti periódusának összetettségét (Tőkés 1998). Éppen ezért szükséges az elméleti keretek szintjén is kelet-európai szemszögből pontosítani a posztszovjet térség posztszocializmusát.

A teleologikus megközelítés hatására - amely a hangsúlyt a jövőre és Nyugatra, mintsem a jelenre és az ittre helyezné - a posztszovjet térség történelmi és földrajzi (helyi) sajátosságai elhomályosodtak (Stenning, Hörschelmann 2008). A tranzitológia bűvkörében a keleti blokk számára legjobb esetben a demokratizálódás normatív felfogásának kritikája jutott (Suchland 2011), de a determinisztikus fogalmak lebontása - például az identitások esetében - egyelőre várat magára. A posztszocializmus tranzitológiával történő megfeleltetését az a tény is szükségszerűen előidézte, hogy a harmadik világ értelmiségi elitjével ellentétben a második világból származó értelmiségiek (pl. Milan Kundera, Czesław Miłosz, Tzvetan Todorov) kritikai attitüdje a szovjet berendezkedés és totalitarianizmus ellen irányult, amely egyszersmind a Nyugat iránti feltétlen szimpátiát is érzékeltetett (Suchland 2011). Ennek következtében a vasfüggönyön inneni és túli világ kapcsolatának kritikai nézőpontja a Szovjetunió lebomlásáig nem került elő. Az orosz/szovjet modell azonban, mint a modernitás 
sajátos variánsa, szintén a Nyugattól átvett és ahhoz viszonyított, azt utánozni próbáló modernitás volt (az ehhez kapcsolódó jelszóval: „Nyugat nélkül utolérjük a Nyugatot") (Tlostanova 2012). Azzal, hogy a második világ tulajdonképpen egyik napról a másikra megszűnt létezni, a nyugati narratívák a posztszovjetet inkább időben és nem térben értelmezték, ami a mai napig hozzájárul a tranzitológia fennmaradásához, valamint a posztkoloniális kritikai szempontok hiányához (Tlostanova 2012).

\section{A posztkolonializmus elméletének alkalmazhatósága a „posztszovjet" társadalmi viszonyaira}

A posztkolonializmus egy olyan szellemi irányzat a humán tudományok területén, amely az utóbbi két-három évtized földrajzi tudástermelését nagyban befolyásolta (Cullen, Ryan, Winders 2013). A posztkoloniális szellemben írt müvek - újragondolva az eurocentrikus filozófiát és historiográfiát - rámutattak a gyarmatosítás folytonosságára a nacionalizmusokban, a szuverenitásban, a hatalom térbeli és hálózati egyenlőtlenségeiben, a tőke felhalmozásában, valamint a demokrácia kiterjesztésének és a tudás megszerzésének korlátolt lehetőségeiben (Sharp 2009). A posztkolonializmus, ellentétben a szocializmus végeszakadtával, kevésbé köthető egy jól meghatározható történelmi eseményhez vagy politikai státuszváltáshoz, sokkal inkább egy kritikai elköteleződést jelez a kolonializmus utólagos következményeivel és ismeretformálásban betöltött szerepével szemben (Gregory 2004; Radcliffe 1997). A posztkoloniális tanulmányok egyik legnagyobb hozadéka, hogy támadták a globális összefüggésekről szóló kinyilatkoztatásokat (metanarratívákat), amelyek a modernizációra, a fejlődésre és a világrendszer-elméletekre épültek. Ezeket viszont szinte kizárólag a nem nyugati, fejlődő országok keretein belül vizsgálták, a második világ nem részesült hasonló figyelemben (Chari, Verdery 2009).

Jóllehet, akárcsak az orientalizmus esetében (Said 2000), Kelet-Európa „másodlagos vagy kettős orientalizmusa egyszerre hagyományos és modern" (Park 2010) és szintén ötvöződött hatalmi, birodalomépítési szándékokkal, de erre a térségre nem a civilizáltság ellenpólusaként vagy a barbarizmus megfeleltetéseként tekintettek, hanem a „kelet-európaiságot” egy fejlődési skála köztes állapotaként azonosították, amely vonatkoztatási pontként segítette elő a nyugati modernitás diskurzusainak létrejöttét (Wolff 1994). A térségben viszont megtalálhatóak a posztkoloniális tanulmányokban gyakran visszaköszönő kreolizáció, hibriditás, többnyelvűség, transzkulturáció sajátos formái, amelyek párhuzamosíthatók posztkoloniális társaikkal (Tlostanova 2012). Érzékletes hasonlóság, hogy a szovjet és posztszovjet nemzeti törekvések nem a nemzetek törekvéseiként, sokkal inkább az intézményesített nemzeti elitek, illetve az ezzel szemben álló ellenelitek küzdelmeként jelentkeztek (Brubaker 1994). A közvetlen szovjet irányítás alatt lévő köztes-, illetve kelet-európai helyzet abban az 
aspektusban is összefüggésbe hozható a posztkolonializmussal, ahogy az adott államok homogenizálni próbálták népességüket egy nemzetállami idea mentén (pl. az 1990-es években a Baltikum országai, manapság Ukrajna), így a kelet-európai nacionalizmusok a posztkoloniális államépítés analógiájaként értelmezhetők (Verdery 1996).

Mindezek ellenére - bár jelentkezett már erre vonatkozó felhívás (Sidaway, Woon, Jacobs 2014) - kevés elmélet terjesztette ki a posztkolonializmust keleteurópai (posztszovjet) irányba. Moore (2006) szerint „a hallgatás” oka egyrészt az, hogy a posztkoloniális kutatók többsége marxistaként nem hajlandó a Szovjetuniót a franciáknak vagy a briteknek kijáró „gonosztevo”" státuszban feltüntetni. Vagyis a nyugati kritikai szakirodalomban „nem lehet egyszerre a marxizmusnak és a gyarmatosításnak is áldozata lenni” (Račevskis 2002, 42.). Másrészt a nyugati értelmiség bűnösnek érzi magát a harmadik világ állapotai miatt, de ugyanezt a szolidaritást nem tartja szükségesnek a második világ irányában (Moore 2006). A posztkoloniális tanulmányok továbbá túlságosan nagy jelentőséget tulajdonítanak a víz elválasztó szerepének, mivel a nyugati államok tengerentúli törekvéseit gyarmatosításnak, az orosz/szovjetet viszont csupán területi expanziónak láttatják (Lazarus 2012). Összességében tehát a második világ különbségei a Nyugathoz képest nem eléggé eltérőek ahhoz, hogy a saidi posztkoloniális "másik” rangjára emelkedjenek (Koobak, Marling 2014).

Ugyanakkor a két „poszt” megfeleltetését számos tényező hátráltatja. Például Moszkva abban a tekintetben is különbözött a nyugati gyarmattartóktól, hogy függő területeit nem tőkefelhalmozással (ezt meghagyta a nemzetállami újraelosztás fenntartásához), hanem a hatalom elosztásával és újraelosztásával kívánta integrálni (Chari, Verdery 2009). Todorova (2010) szerint ezzel együtt sem beszélhetünk (Köztes-)Európa szovjet gyarmatosításáról, mert ezen államok - szemben például az afrikai gyarmati rendszerrel - jelentős mértékben megőrizték társadalmi folyamataik feletti ellenőrzésüket, ezért a „posztkoloniális paradigma" helyett a konkrét történelmi hagyatékok felőli megközelítést tartja indokoltnak. Kovačević (2008) ugyan egyetért azzal, hogy egyetlen európai államot sem ért az Afrikához vagy Ázsiához mérhető gyarmati kizsákmányolás, ugyanakkor véleménye szerint ezzel a gondolkodással a Nyugat által teremtett sztereotípiákhoz (lenézett, elmaradott vagy a mitologizált konzervativizmus dichotómiái) rögzítjük a térséget, amely helyett inkább egy sajátos kelet-európai orientalizmusra van szükség. Mivel nincs konszenzus a gyarmatosítás definíciójáról és területi kiterjedéséről, ezért a posztszocializmust - mint kiüresedett címkét - inkább egy deterritorializált állapotként (Tuvikene 2016) célszerű értelmezni annak érdekében, hogy azt a posztkolonializmus gazdag elméleti vívmányaival telíthessük (Owczarzak 2009). Ez az episztemológia Todorova álláspontjával is egybevág, amely a posztkoloniális elméleti keretek elutasítását csak a tárgy oldaláról tartja elfogadhatatlannak, hiszen a szubjektum szemszögéből vizsgált öngyarmatosítás és az ehhez kapcsolódó gyakorlatok más szempontokat is érvényesítenek. Ebben a megközelítésben a periféria szubjektumai 
önmagukat marginalizálják, amellyel állandósítják a centrumot (Kiossev 2011). Koobak és Marling $(2014,336$.$) szerint éppen ,az öngyarmatosítás komplex és$ szüntelen folyamata" miatt lesz a posztszocialista régió releváns a posztkoloniális tanulmányok számára.

A posztkoloniális kritikai szempontok bevezetése lehetőséget teremt a megmerevedett dichotómiák szétszakításához, a külső hatalmi centrumok igényei szerint formált hierarchiák, valamint a korábbi évtizedek egyirányú hatásai alatt őrlődő társadalmi logika kötöttségeinek lebontásához. A „posztkoloniális posztszovjet" megközelítés így szükségszerűen kritikus a piacgazdaság és a demokrácia neoliberális ígéretével, a szocialista múlttal és a szocialista jövőképekkel, valamint a tudás megszerzésének lehetőségeivel szemben. A politikai-hatalmi viszonyoktól terhes, bináris ellentétekre épülő viszonyok helyett a kulturális mintázatok újraértelmezésével a posztkoloniális tanulmányokból kölcsönzött hibriditás (lásd bővebben Bhabha 1994) alkalmas lehet a rendszerváltások utáni ellentmondások, ambivalenciák és ijesztő kontrasztok megragadására, értelmezésére. Az így megfogalmazott „posztszocialista hibriditás” kiutat jelenthet a szocialista kísérlet végét sirató baloldali narratívák és a szocialista érát démoni totalitárius elnyomásként ábrázoló ellenoldal áthidalhatatlan konfliktusai között (Marciniak 2009). Emellett a hibriditás emlékeztet minket arra, hogy a kultúrák nem szükségszerüen homogének és koherensek.

Az európai posztszocialista térség nyugati részének államaiban a sajátos történelmi örökség, a nyugati orientáció nyomán ugyanakkor kérdéses, sőt erőltetett lehet a posztkoloniális nézőpontok felhasználása, viszont a keleti, posztszovjet térségben a társadalmi folyamatokat döntően meghatározó erőtlen helyi struktúrák, a folyamatos kiszolgáltatottság és a moszkvai gyarmatosító törekvések intenzívebb hatása összességében a posztkolonializmus elméleti keretként történő alkalmazását teszik lehetővé, illetve indokolttá. Mindenesetre szükséges elkerülni, hogy a korábbi, holisztikus episztemológiát újakkal helyettesítsük. Ahogy Tlostanova $(2012,132$.$) rámutat: „az előre gyártott diskurzusok$ és utazó elméletek univerzalista alkalmazása" helyett a különböző - koloniális és imperialista különbségek által meghatározott - helyi történelmek feltárása lehet a cél, elkerülve mind a hősies ellenálló, mind az áldozati bárány szerepkörét. Ugyancsak elkerülendő a posztszocializmus (vagy éppen a posztkolonializmus) jelentőségének túlhansúlyozása, amely a historicizmus csapdájával fenyeget (Stenning, Hörschelmann 2008). Erre a problémára megoldást jelenthet, ha a posztszocializmust nem pusztán periodizálásra használjuk, ezáltal a pre- és posztszocializmus közötti metszéspontok felfedésével lehetőség nyílik az osztályozások újragondolására. Így a posztszocializmust nem a posztkolonializmus egyik változataként szükséges aposztrofálni, hanem heurisztikus módon a posztkoloniális tanulmányok szempontrendszerét kell érvényesíteni a posztszovjet identitások árnyaltabb értelmezéséhez. A moldáv identitás, valamint sajátos térbeliségének vizsgálata alkalmas kiindulópontot jelent, hogy eleget tegyünk a fenti felhívásnak. 


\section{A jelenségek földrajzi léptékeiröl}

Az elméleti alapokon kívül a kérdéskör rétegzettsége és összetettsége megkívánja egy olyan gondolati ív lefektetését, amely kísérletet tesz a hazai etnikai-, vallás- és politikai földrajzi tanulmányokban honos historicizáló narratívák meghaladására. Tanulmányunkban ehhez a lépték fogalmát hívjuk segítségül. Mint később látni fogjuk, a moldáv identitást befolyásoló tényezők szupranacionális, nemzeti, regionális és lokális szintek mentén elkülönülő és egyben összefonódó vonatkozásai a lépték használhatóságát támasztják alá. Jóllehet a lépték az 1980-as évektől kezdődően a földrajzi vizsgálatok rendszeresen megjelenő koncepciójaként szolgált, az 1990-es évektől kibontakozó léptékvitában előbb elveszítette magyarázó erejét, végül pedig ontológiai státuszát (Berki 2017). A vita kicsúcsosodásának Marston, Jones és Woodward (2005) tanulmánya tekinthetö, amely a léptéket nemcsak terméketlen, hanem egyenesen káros földrajzi alapkategóriaként azonosította. Manapság a szakirodalomban óvatos visszarendeződés tapasztalható, amelynek célja a lépték módszertani hasznosságának (legalábbis részleges) visszaszerzése a vizsgált társadalmi folyamatok rendszerező eszközeként (Häkli 2018). Hangsúlyoznunk kell, hogy a nemzetközi trendeknek megfelelően, illetve a globalizációval felerősödő áramlások, kölcsönhatások és hálózatok jelentőségére való tekintettel nem kívánjuk a léptéket se materiális, se determinisztikus jelleggel felruházni, sokkal inkább episztemológiailag tekintünk rá (Jones 1998). Ennek megfelelően vizsgálatunkban nem feltételezünk hierachikusan meghatározott folytonosságot a moldáv identitás rétegeire rávilágító lokális és globális szintek között, hanem az identitás elemeinek dinamikusan változó jellegére hívjuk fel a figyelmet.

\section{A moldáv identitást meghatározó szupranacionális lépték}

A mai önálló, modern moldáv állam alapjait a 19. század elején rakták le, határai pedig (leszámítva északnyugati részét) 1940 augusztusában alakultak ki, amikor a Szovjetunió egyik tagköztársasága lett. Ez a politikai keret nem folytatása a 15. században fénykorát élő Moldvai Fejedelemségnek. A terület politikai rajzolata többször változott, leginkább a szomszédos hatalmak aspirációi miatt. Így a moldáv identitást leginkább a szupranacionális elemek alapozták, majd határozták meg a későbbiekben, és így jutott el a sztálini nemzetiségpolitika bugyrain keresztül a ma megfigyelhető többrétegü állapotába.

A térség egy olyan átmeneti területen található, ahol a történelem során megjelenő nagyhatalmak politikailag/katonailag nem voltak elég erősek ahhoz, hogy az itt élőket stabil gazdasági struktúrájú államalakulatba integrálják. Ugyanakkor a fokozatosan kialakuló helyi vezető politikai réteg nem tudott a külső befolyásnak ellenállni és tartós államot kialakítani, illetve megerősíteni 
(Siupur 1993). Ezért évszázadokon át a koloniális beavatkozások erős hatást gyakoroltak a környezetétől nyelvileg, kulturálisan egyébként markánsan elkülönülő népességre. Ennek eredménye a terület átmeneti jellege, amely a meghasadt identitáskonstrukciók fluiditásában és több, megkésett nacionalizmusban is megmutatkozik.

\section{A moldáv identitás kialakulásának feltételei}

A moldáv identitás egyik alapja az a politikai formáció, amely a vizsgált térségben élő, keresztény kötődésű, újlatin nyelvet beszélő csoportok számára biztosított keretet. Bár a modern nacionalizmusok stabil alapját a modern állam struktúrái jelentik, sok köztes- és kelet-európai esetben ez nem feltétlenül jogi folytatása az ugyanazon a néven létezett középkori előzményeknek, bár térségünkben ezek az államalakulatok a kollektív emlékezetben fontos szerepet játszanak. Így a moldáv államiságnak is olyan elemei fejlödtek ki az idők során, amelyek erősen beleivódtak a jelenlegi Moldovai Köztársaság társadalmába.

A mai Moldova tágabb környezete az 5-13. század időszakában a lovas nomád törzsek felvonulási területeként funkcionált. Ez a tény járult hozzá leginkább ahhoz, hogy szilárdnak mondható állami struktúra csak a középkor utolsó harmadában alakult ki, jóllehet a térség stratégiai jelentőségét felismerve a környéken formálódó államok (pl. Kijevi Rusz, Magyarország vagy Lengyelország) már korábban is szívesen integrálták volna e területet országukba. Így a mongol hadak felvonulási területévé váló térségben, amely leginkább magyar fennhatóság alatt állt, az első szilárdnak mondható államot, a független Moldvai Fejedelemséget 1359-ben alapította Bogdan herceg. A fejedelemség területét, központi tengelyében a Prut folyóval, keleten a Dnyeszter, délen a Fekete-tenger és az Al-Duna, míg nyugaton a Kárpátok (pontosabban a Magyar Királyság keleti határa) foglalta keretbe. Csupán északon, a lengyel térségek felé hiányzik a stabilabb természet- és politikai földrajzi határ. Ezért ebben az irányban a pufferzóna hatásai is erőteljesebbek (Hausleitner 2008) (1. ábra).

A terület pufferzónajellege a későbbiekben sem változott, és a külső erők gyengesége vagy inkább hatalmi egyensúlya miatt a terület 15 . századi fénykorát követően az ekkor a Balkán és a Krím irányába különösen dinamikus külpolitikát folytató Oszmán Birodalom vazallusa lett. A térséget az oszmánok nem integrálták államukba olyan formában, mint például balkáni területeiket. Sőt, egy bizonyos kulturális önállóság - főleg az oszmánok számára stratégiailag kevésbé fontos és ezért kevésbé heterogén etnikai térszerkezettel bíró északabbi térségekben - folyamatos volt (Kőszegi 2016a). E tények határozták meg, hogy a területen létrejött egy nyelvi, kulturális alapszövet és politikai értelemben is bizonyos mértékủ kohézió, amely a folyamatos hatalomváltások és külső (ellen)hatások ellenére a mai napig megmaradt, és a társadalom identitásának egyik fontos rétegét jelenti (Neukirch 2003). 
1. ábra: A Moldovai Köztársaság mai területének határváltozásai a 14. századtól napjainkig Boundary changes on the contemporary territory of the Republic of Moldova since the 14th century

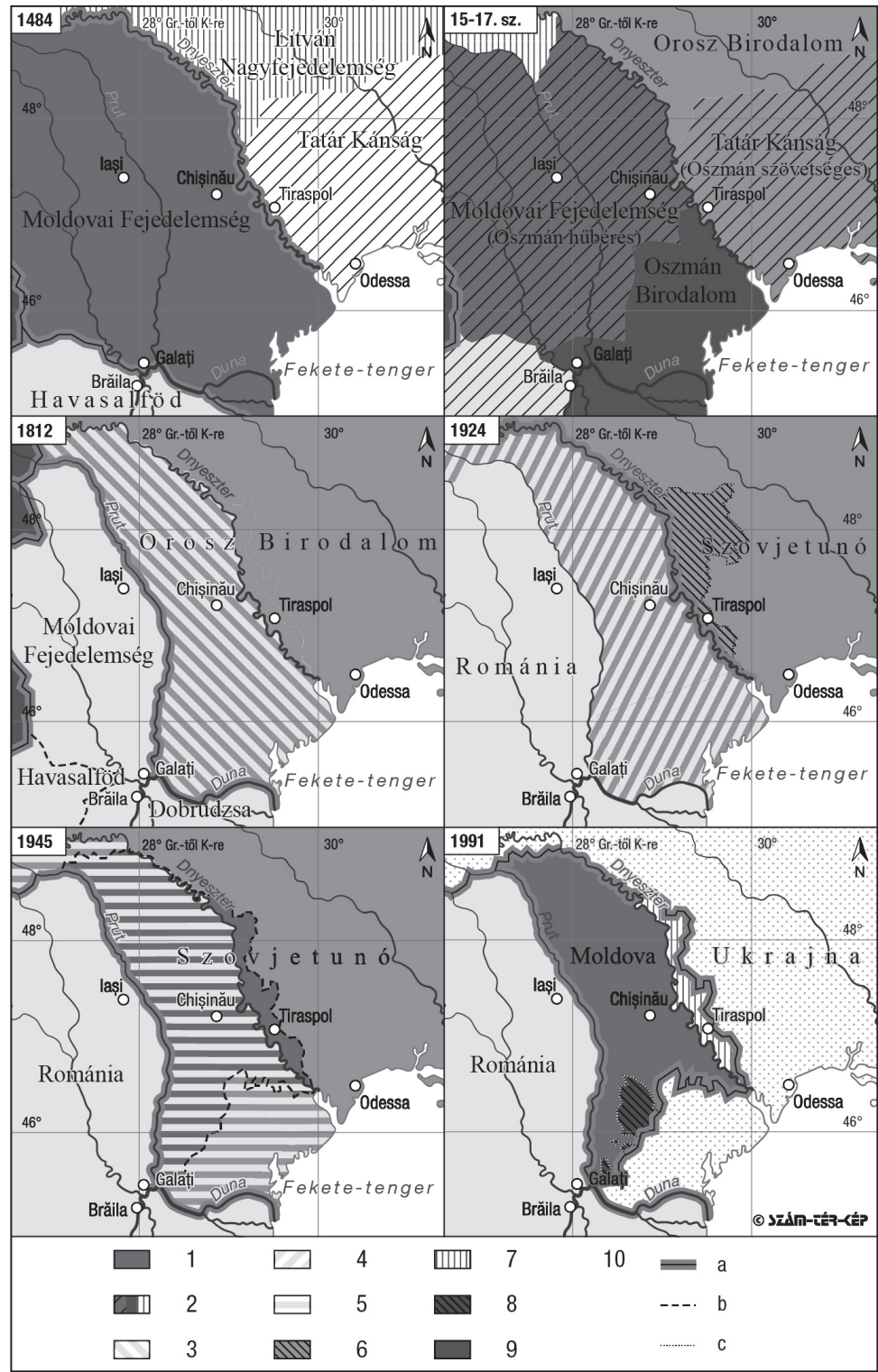

Jelmagyarázat: 1. Moldova területe 1389-1432 között; 2. Moldova területi veszteségei 1484-1812 között; 3. A bukaresti békében (1812) az Oszmán Birodalomtól Oroszországhoz került terület; 4. 1918-ban Nagy-Romániához került terület; 5. 1940-1941 között a Szovjetunió által elfoglalt, 1944-tól annektált terület; 6. A Moldáv Autonóm Szövetségi Szovjet Köztársaság; 7. Dnyeszter Menti Köztársaság; 8. Gagauz Autonóm Terület; 9. Habsburg Birodalom; 10. Határok: a. országhatár, b. szövetségi határ, c. autonóm terület határa.

Forrás: Sellier, Sellier (1991); www.historymaps.ro. 


\section{A külső hatások felerősödése}

A 18. század végétől a Köztes- és Kelet-Európában is megfigyelhető liberalizmus szellemében a térség lakosságának nemzeti alapon történő integrálása is fölmerült. 1812-től azonban a korábbi Moldovai Fejedelemség története két eltérő úton haladt, ahol a történések a helyi lakosság csoportidentitását a hasonló alapszövet ellenére is eltérő irányokba terelték (Tontsch 1996). A nagyjából a

2. ábra: Az oroszországi románok településterületének etnikai összetétele 1897-ben

Ethnic composition of the settlement area of Romanian population in the Russian Empire (1897)

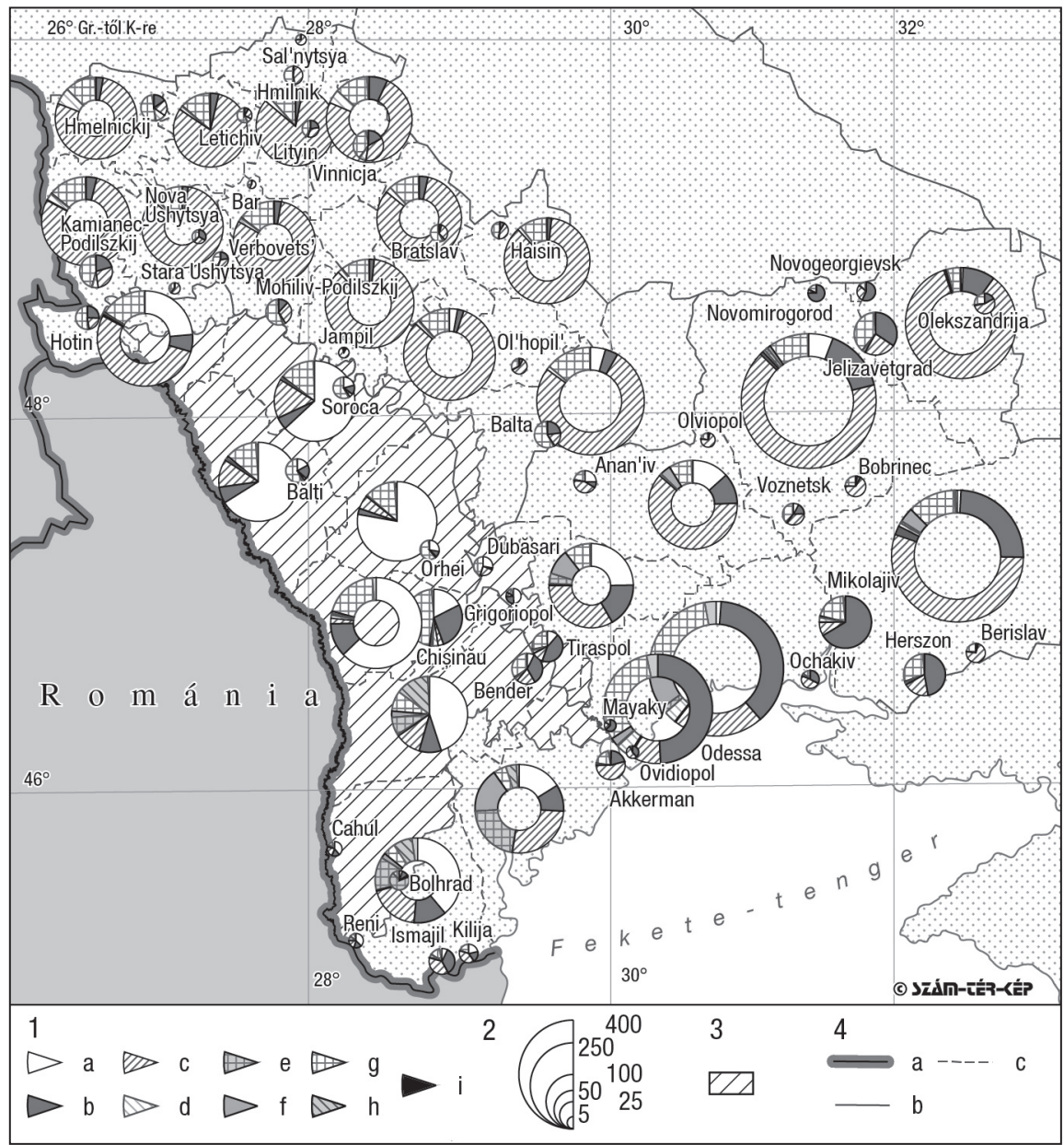

Jelmagyarázat: 1. A lakosság anyanyelvi megoszlása: a. román, b. orosz, c. ukrán, d. lengyel, e. bolgár, f. német, g. zsidó, h. egyéb; 2. A lakosság száma (1000fö); 3. A mai Moldovai Köztársaság területe; 4. Határok: a. országhatár; b. guberniumhatár; c. ujezdhatár.

Adatok forrása: Oroszországi népszámlálás 1897. 
Prut és a Dnyeszter közötti, Besszarábiának nevezett terület a korabeli orosz külpolitika törekvései, a Balkán irányába kifejtett területi aspiráció következtében az Orosz Birodalom részeivé váltak. E tény miatt e terület alapvetően más pályára került, változott geopolitikai orientációja, valamint a 19. századi nemzetépítési stratégiák is máshogy érintették (Zabarah 2013).

A területen a cári Oroszország birodalomépítési logikájából következően a közigazgatás nyelvének és annak kultúrájának támogatása élvezett prioritást (King 2000). Ennek következményeként a térségben megnövekedett az orosz nyelv és kultúra befolyása, az 1860-as évektől pedig fokozatosan korlátozták a román nyelvet az oktatásban és az egyházi liturgiában. A 19. század első felében a lakosság etnikai térszerkezete is kezdett átformálódni. Ez a román nyelvűek a Pruttól nyugatra fekvő Moldvai Fejedelemségbe történő fokozatos kivándorlását, míg a belső orosz térségekből, főként az adminisztráció és a gazdaság területére az orosz nyelvüek érkezését jelentette (Cazacu, Trifon 2017). Így a román nyelvüek fokozatosan a vidéki térségekbe szorultak, míg a városokban leginkább a zsidók mellett a szláv nyelvüek kerültek csaknem kizárólagos többségbe (Bochmann et al. 2012) (2. ábra).

Ezzel szemben a Kárpátok és a Prut között húzódó, továbbra is önálló Moldvai Fejedelemségben a Havasalföldi Fejedelemséggel történő nyelvi, kulturális egység megteremtése volt a cél, amivel lényegében a politikai pozícióját erősíteni kívánó románság nemzetté válása folyt. Viszont az így nemzetté formálódó, Kárpátokon túli csoport az erdélyi és bukovinai románokkal állt sokkal intenzívebb kulturális kapcsolatban, míg a besszarábiai románság többnyire kimaradt a nemzeti összekovácsolódás élményéből (Goina 2005). E folyamat keretében a román nyelv modernizálása, sztenderdjeinek közelítése, illetve nyugati orientációja is egyre inkább előtérbe került. 1860-tól szakítottak például a cirill ábécé használatával (ami a Pruton túl egészen 1918-ig megmaradt), valamint kigyomlálták a szláv szavakat (Solomon 2002).

\section{A geopolitikai helyzet meghatározottságai}

Az 1812-től kialakult gazdasági és társadalmi különbségeket a terület 1918-ban bekövetkező Romániához csatolásával sem sikerült a román hatalomnak csökkenteni. Ennek egyik oka, hogy a Szovjetunió nem ismerte el Románia jogát a Pruton túli területekre, így a csatlakozás kezdettől veszélyeztetve volt külpolitikailag. Éppen ezért volt elsődleges cél román részről a csupán 56\%-os román/moldáv többséggel rendelkező terület minél gyorsabb és esetenként minél agresszívabb integrálása (van Meurs 2003). Az erősödő kormányzati centralizáció és a restriktív nemzetiségpolitika viszont nemcsak a nem román nyelvüek ellenszenvét váltotta ki, hanem a nagyobb fokú szubszidiaritáshoz szokott, tradicionális életvitelt folytató moldáv lakosság elégedetlenségét és marginalizálódását is felerősítette (Petrescu 2001). 
Ezzel párhuzamosan 1924-ben szovjet részről létrehozták a Moldáv Autonóm Szocialista Szövetségi Köztársaságot az Ukrán Szocialista Szövetségi Köztársaságon belül. Az autonóm terület kialakítása egyrészt azzal a szándékkal függött össze, hogy a szovjet stratégiai érdekeknek megfelelően jelezzék igényüket a Prut és a Dnyeszter közötti, egykor orosz fennhatóság alatt álló területekre, másrészt a térség kiindulópontjaként szolgálhatott a Romániát gyengítő diverzáns akcióknak (Cazacu 1996). Emellett ez biztosított állami keretet a moldávok különálló nemzeti identitásának is, amely a terület ismételt Szovjetunióhoz történő csatolása (1940), illetve még inkább 1944 után tovább erősödött.

Ettől az időszaktól a Moldáv SZSZK és Románia társadalma egymástól távolodott (Berindei 1996). Míg Romániában a Pruton túli területekkel való történelmi, kulturális kapcsolatok ápolása, de még emlegetése is az 1960-as évekig tabutémának számított, addig a határ túloldalán nemcsak az államhatár jelentett gátat, de módszeresen emeltek falat a két ország hasonló kulturális gyökerü társadalma közé. Bár a Ceaușescu nevével fémjelzett időszakban a kérdésben némileg változott a helyzet, de a „besszarábiai kérdés” továbbra is a politikaiideológiai párharc mellékszála maradt (Tontsch 1996; van Meurs 2003).

Az egész Szovjetunióban, így a Moldáv SZSZK-ban is a szovjet politikai rendszer, illetve életmód, kultúra terjesztése volt megfigyelhető, amelynek a keretében egyre nagyobb hangsúlyt kapott a térség újlatin nyelvet beszélő csoportjainak a romántól való kulturális és történelmi különállásának hangsúlyozása. Ezt erősítette a cirill ábécé újbóli bevezetése, a román irodalmi nyelv háttérbe szorítása, a romanofil értelmiségiek deportálása (ezzel párhuzamosan a belső orosz vidékekről munkások és egyéb funkcionáriusok letelepedésének elősegítése), illetve a már említett román etnikai törzsterülettel való fizikai és kulturális kapcsolatok akadályozása (Dumbrava 2002; Illés 2018b).

\section{A nemzetépítés - önálló politikai keretben}

\section{A szovjet embereszménytól az önálló identitásig}

Jóllehet a Szovjetunió az 1980-as évek elején még többé-kevésbé sikeresen szorította vissza a helyi ellenzéki politikai csoportokat, az évtized második felében a „politikai fiatalítást” jelző Gorbacsov pártfőtitkárrá történő előlépése, illetve a peresztrojka és a glasznoszty alapvetően más helyzetet teremtettek, már a szovjet rendszer összeomlását jelezték. Ennek Moldova esetében az első kézzelfogható jelei 1989 augusztusában, a román kultúrával szorosabb kapcsolatot ápoló, a politikai és gazdasági hatalomból kimaradt, azt megragadni szándékozó elit vezette Népfront (Frontul Popular) szorgalmazta intézkedések; a román nyelv hivatalos elismerése és a latin ábécé bevezetése voltak (Solomon 2002). 
Ezzel párhuzamosan a Moldáv SZSZK, kihasználva a nagyobb politikai mozgásteret, igyekezett szorosabbra füzni a viszonyát Romániával, jóllehet az 1991 áprilisában történt Iliescu-Gorbacsov-találkozón aláírt egyezmény egyik pontja éppen a határok sérthetetlenségét mondta ki. A Romániához való közeledést, illetve a politika szintjén egyre inkább emlegetett egyesülést számos egyéb jel is mutatta. Ennek ellenhatásaként körvonalazódott egy orosz orientáció mellett érvelő (a régi struktúrák fenntartásában vagy azok minél szélesebb körű átmentésében érdekelt) politikai csoportosulás is. Ők döntő többségükben a Dnyeszteren túli területek és a főváros kommunista elitjéből, illetve a moldáv többség ellenében a korábban a szovjet rendszertől engedményeket kapó gagauz és bolgár kisebbség köreiből verbuválódtak (March 2007).

1991 augusztusában a Moldáv SZSZK Moldovai Köztársaság néven kikiáltotta függetlenségét, szinte ezzel egy időben deklarálták ugyanezt a gagauzok és a Dnyeszteren túli területek fóként orosz és ukrán nyelvü lakói is. A kirobbant polgárháború során a Szovjetunió 1991. decemberi megszünésével Moldova de jure is függetlenné vált. Ugyanakkor a hathatós orosz támogatással bíró szeparatisták a nemzetközi diplomácia által el nem ismert Dnyeszter Menti Moldáv Köztársaságot alakították ki, míg Gagauzia néven egy autonóm terület keletkezett.

Amint látható, a Moldovai Köztársaság államiságát, de sok esetben lakóinak identitását is történelmi távlatokban leginkább a szupranacionális erők határozták meg, és csak egy viszonylag rövid időszakban jutott érvényre a helyi elit akarata. Az önálló Moldovai Köztársasággal viszont úgy tűnhetett, megteremtődtek a feltételek arra, hogy a területen élők nemzeti szinten saját elképzeléseik mentén határozzák meg önmagukat. Ugyanakkor a fent végigvezetett hatalmi kitettségek, a belső társadalmi struktúrák, illetve az Európa keleti felén jellemző identitáselemek (leginkább a nyelv szerepe, a szovjet időszakban a vallás periferikus helyzete, valamint a történelmi múlt feldolgozatlansága) ellentmondásossá tették az ország lakóinak önazonosságát, amelynek posztkoloniális útkeresése a rendszerváltás óta éles társadalmi problémák kiindulópontja.

Az új helyzetben kívülről nézve két külpolitikai stratégia látszott megvalósíthatónak az új állam stabilizálásához, ami feltétele volt az új gazdasági struktúrák kialakításának is: egyesülés Romániával vagy a két román állam koncepciója. Míg a nemzetépítés a posztszocialista országok többségében a kisebbségek integrálásának, illetve egy európai identitás kialakításának folyamatát jelentette, más a helyzet a föderális egységeik mentén szétszakadt államok (Jugoszlávia, Szovjetunió) esetében, amelyek részei sok esetben hirtelen váltak új (nemzet)államokká. Az így újonnan létrejövő országok között Moldova speciális abban az értelemben, hogy egyrészt keletkezésének pillanatában kérdöjelezték meg létét, másrészt a kialakuló/kialakítandó moldáv identitás 100 évvel ezelőtti előzménye sem eredményezett stabil azonosságtudatot, ráadásul Transznyisztriában a függetlenedéssel párhuzamosan egy új nemzeti mozgalom is definiálta magát. 


\section{Identitásmenedzsmentek az önálló Moldovai Köztársaságban}

Az országban az 1990-es évektől a nemzetépítés három iránya bontakozott ki, melyek rövid idő múlva politikai nézetekként is értelmezhetők voltak (Solomon 2002; van Meurs 2003). Az egyik irány az ún. „román vonal”, amely az újlatin nyelvet beszélőket románnak tekinti és a Romániával való egyesülést tartja követendő célnak. Ennek tulajdonképpen ellenpontja a „moldáv vonal”, amely a történelmi gyökerek és a helyi sajátosságok miatt a moldáv etnikum léte mellett érvel és önálló (nemzet)politikát tart követendőnek. Az 1990-es évek első felének eseményei, leginkább persze a Dnyeszter Menti Moldáv Köztársaság létrejötte hívta létre az ún. „transznyisztriai vonalat”, amely az önálló „ország” jogalapjának az önálló, helyhez kötődő transznyisztriai identitást tekinti (Sieg 2011).

Mindhárom politikai irányzat elsősorban az identitásnak azt a további léptékét hangsúlyozza, amely leginkább érveket szolgáltat léte számára. A „román vonal" a nemzeti szintet helyezi előtérbe, amely a történelem során megfigyelhetö orosz terjeszkedés ellenében az újlatin nyelvet beszélő tömegeket kultúrnemzeti alapon románként integrálná. Így számára a cél jelenleg is a két országrész egyesítése. Az évszádos orosz fennhatóság - szerintük - csak letérítette a jelenleg a Moldáv Köztársaságban élo „román” csoportokat a korábbi közös útról. Ebben a vonalban egyértelmủen a nyugati orientáció jelenik meg.

A „moldáv vonal” ezzel szemben, válaszként a sajátos geopolitikai helyzetre a lokális szintet helyezi előtérbe, hiszen ez az a lépték, ahol a „moldávok” sajátosságait ki lehet emelni (Belina, Arambasa 2007). A Pruton túli újlatin nyelvű csoportok között - néhány történeti időszakot leszámítva - a 19. század elejétől az Orosz, majd 1940-től a Szovjet Birodalom perifériáján az oroszosítás, a szovjet embereszmény oktrojálása közepette az egyén túlélése nagyban a közvetlen környezetétől, illetve szűkebb környezetének, közösségének erejétől függött (Tî̂cu 2018). A középkori tradicionalizmusában „megrekedt” moldáv lakosság pedig különösen kötődött a rurális terekhez, így a nagyobb léptékben gondolkodó identitásmenedzsmentek (orosz, román vagy szovjet) nem tudták mobilizálni a vidéki tömegeket (Cusco 2017). Tehát a többnyire rurális területen a moldáv lakosság lokalitásával nem összeegyeztethető gyarmati logikájú nemzetépítés nem fejtette ki várt hatását, a helyiek pedig később elszigetelődtek mind a szovjet hatalom által etnikailag is uralt nagyobb városoktól, mind pedig a román nemzetépítés fó áramlataitól. A kettős elidegenedés által létrehozott öndefiníció (egyben politikai magatartásforma) manapság leginkább a moldovanizmusban ragadható meg, amely egyetlen külső lehetséges geopolitikai irányt sem tart követendőnek és Moldova területi szuverenitásában, illetve függetlenségében érdekelt (Benkö, Malek 2005).

A „transznyisztriai vonal” számára - az előző két vonal ellenpólusaként - a regionális szint az elsődleges, miután egy jól körülhatárolható területen hozták létre az állami kereteket (a Dnyeszter bal partján fekvő területsáv és két, a folyótól nyugatra lévő hídfó). Emellett az ország déli részén található a Gagauz 
Autonóm Tartomány, ahol a török nyelvű, ortodox vallású népesség élvez autonóm jogokat. Mindkét térség abszurd nosztalgiával áthatott regionalizmusa az orosz/szovjet korszak kulturális politikáira épül, amely megvédte őket a román/moldáv nemzeti törekvésektől (Kőszegi 2016b). Transznyisztira önállósága elsősorban Oroszország geopolitikai érdekeltségének tulajdonítható, míg a gagauzok autonómiája éppen a szakadár területek kialakulása miatti kompromisszumnak köszönheti létét a moldovai vezetés részéről.

A moldáv/román identitásmenedzsmentnek - különösen a transznyisztriai területen - egy önálló, jelenleg is formálódó csoport újonnan konstruált identitásával kell számolnia. A rendkívül heterogén etnikai összetételü terület (3. ábra) lakói a történelmi időkben is köztes identitással rendelkeztek, amely esetlegessé tette ezen a területen a román nemzetegyesítési elképzeléseket (Zabarah 2013). A rendszerváltás után a szeparatisták érvei a moldáv/román dominancia ellen irányultak, hiszen egy esetleges struktúraváltás a szovjet időszakban szerzett gazdasági előnyöket is veszélybe sodorta volna. Ezért Transznyisztria szuverenitásának, önálló nemzeti stratégiájának megfogalmazása számított elsődleges célnak (Heller, Arambașa 2009). Tehát miközben a román vonallal szemben a moldáv vonal multietnikus irányt fogalmaz meg, a transznyisztriai identitásmenedzsment de facto államiságának kíván kulturális jogalapot biztosítani.

Az átmenet óta eltelt időszak posztszocialista (de leginkább posztszovjet) Európájának azon részei, ahol az államhatalom nem túl erős, a reformakarat gyenge, a nyugati minták átvételének (pl. az EU-csatlakozás formájában) igénye kicsi és emellett etnikai feszültségek fenyegetnek, indirekt módon is a külső hatalmi játszmák kereszttüzébe kerülnek. Az orosz energiahordozóktól és a nyugati pénzügyi segítségtől egyszerre függő Moldovában ezt látjuk, különösen azért, mert az etnikai különbségeknek erőteljes politikai meghatározottságuk is van. Ez utóbbit, dacára a fegyveres konfliktussá éleződött feszültségeknek, a nemzetközi közvélemény nem érzékelte igazán az 1990-es évek elején, ami a térség elhanyagolt státuszának következménye.

Ugyanakkor ezek az országok sokkal érzékenyebbek a külső nyomásra, ami az állam- és nemzetépítést illeti. Az alapdilemma az, hogy amennyiben a helyi társadalom jelentős része (nagyrészt a média, illetve a politika hatására) moldávnak, vagy egy konkrét régióban, a Dnyeszteren Túli Területen transznyisztriainak definiálja magát, akkor az ezt tagadók hiába érvelnek a „hibás” önazonosítás ellen, hiszen ezzel abba a csapdába esnek, hogy oktrojálni kénytelenek saját nézőpontjaikat a társadalomra. Ilyen módon a nemzeti identitás, illetve annak építése a szupranacionális szintre érkezik vissza Moldova esetében, amit a globalizáció hatásai csak tovább fokoznak.

Az egyre intenzívebbé váló áramlási formákkal az eleve sokrétű és rendkívül komplex moldáv identitások új dimenziókkal egészülnek ki a helyekhez kevésbé köthető, többes identitások formájában. Így a (sokszor transznacionális) mobilitásra való hajlandósággal a szubjektum nemzeti kötődése egy progresszí- 
3. ábra: A Moldovai Köztársaság etnikai összetétele rajonok szerint 2004-2014-ben The ethnic composition of the Republic of Moldova, by raions (2004-2014)

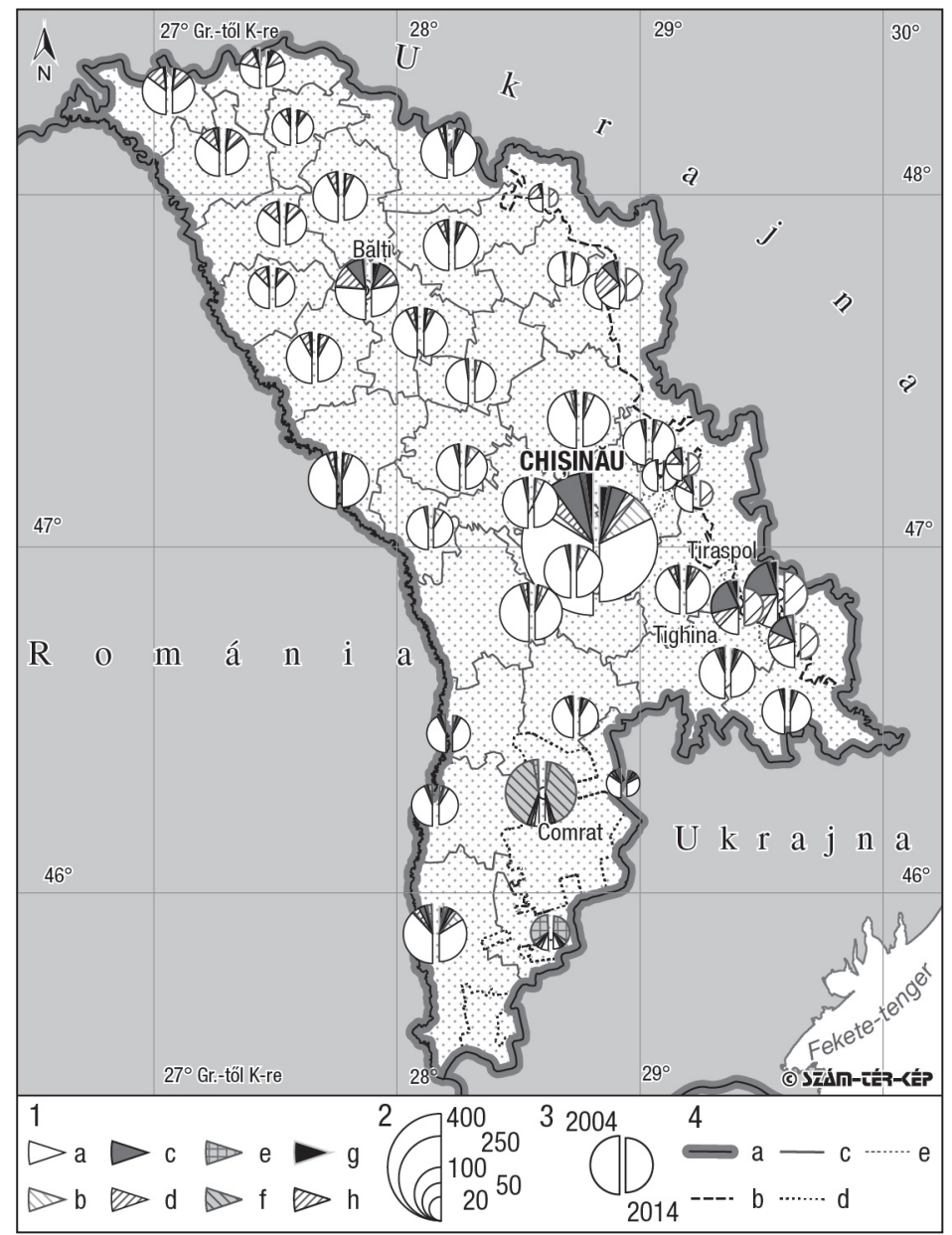

Jelmagyarázat: 1. A lakosság etnikai összetétele: a. moldáv, b. román, c. orosz, d. ukrán, e. bolgár, f. gagauz, g. egyéb, h. a transznyisztriai területegységek lakossága; 2. A lakosság száma (1000fó); 3. A lakosság etnikai összetétele (2004, 2014); 4. Határok: a. országhatár, b. Transznyisztria és Moldova nem hivatalos határa, c. rajonhatár, d. a Gagauz Autonóm Terület határa, e. vitatott területek határa.

Forrás: Biroul Național de Statistică (2004, 2014); Atlas DMR (2004).

vabb, önreflexív választás eredménye lesz, semmint egy társadalmilag konzerválódott struktúra automatikus elfogadása. Gazdasági helyzete nyomán a Moldovai Köztársaság kifejezetten érintett a fluid identitásformák terjedésében, hiszen csak a 2005-2010-es időszakban az ország munkavállalási korú népességének legalább 20-25\%-a tartósan külföldön dolgozott (Nita 2016). Szintén a globális folyamatok térnyerésének és az ezzel járó hálózatosodásnak tulajdoníthatóan a nemzeti identitás már nem kapcsolható kizárólagosan a nemzeti 
szinthez, mivel a globalizáció kibillentette a nemzeti szinten szerveződő társadalmi viszonyokat, valamint fokozta a szub- és szupranacionális léptékek jelentőségét (Brenner 1999). Fontos ugyanakkor megjegyezni, hogy a léptékváltás nem járt együtt a nemzeti identitások relevanciájának alkonyával (Antonsich 2009). Sokkal inkább azt tapasztaljuk, hogy a nemzeti identitás a szupranacionális és regionális identitások különböző formái közé ágyazódik, de ez a három lépték nem statikus módon, hanem egymással kölcsönhatásban egészíti ki vagy éppen teszi lehetővé egymást (Kaplan 2018). Így a moldáv identitás sem köthető csupán a nemzeti szinthez (hiszen azt a kollektív emlékezet nem köti sem egy többszáz éves államalakulathoz, sem egy objektíven definiálható nyelvhez), hanem relatívan értelmezhető, amelynek az egyes szinteken megnyilvánuló rétegei nem önmagukban, hanem egymással szoros összekapcsoltságban és függésben állnak.

\section{Összefoglalás és kitekintés}

A moldáv nemzeti identitás - ahogy a fentiekben láttuk - rendkívül rétegzett, ugyanis a moldáv nacionalizmusok egy átfogó keretrendszer helyett számos olyan, időben és térben összefonódó konstrukcióból táplálkoztak a helyhez kötődő, premodern elemek mellett, mint a modernizáció, az elitek projektje, valamint az ellenállás és kirekesztés nyomán létrejött önvédelmi mechanizmusok. Ezek mellett jelenik meg a nemzeti projekt kulcselemeként a nyelv. Ugyanakkor a globalizáció a nemzetépítést is kihívás elé állítja, amelynek során a korábban jellemzett lokális, regionális, nemzeti és a már globális kulturális javak megjelenését magában hordozó szupranacionális léptékek keveredését tapasztaljuk.

Mindezek alapján a moldáv identitás tanulmányozásánál az „idejétmúlt” strukturalista, valamint a „divatos” posztesszencialista megközelítéseknek (lásd bővebben Malešević 2003) egyaránt van relevanciájuk. Előbbi a szubjektum ágenciáját elvetve az identitást társadalmilag meghatározottnak tekinti, amely esetünkben a relatív nyugalmat biztosító szovjet korszak struktúráinak (jelenleg is érvényesülő) erőteljes beágyazottságában köszön vissza. Másfelől a posztesszencialista identitáskoncepció moldovai érdekessége, hogy az nem csupán egy posztmodern állapot eredményeként fluid (összefüggésben a növekvő migrációs kényszerrel), hanem azért is, mert az identitás építókockái egymásba csúsznak és összemosódnak, amint ezt a léptékek szerint vizsgálva is láthattuk. A lokálisan értelmezhető réteg ugyanúgy kifejezésre jut a nemzeti szinten (pl. a „moldáv vonal", amely a hely szelleméből táplálkozó autenticitás és tradicionalizmus elemeire épít), mint a nemzeti szint a lokális szinten keresztül (pl. az időről időre fellobbanó, román vagy orosz külpolitikai közeledést elutasító tüntetések).

Ugyanakkor a moldáv identitás a posztkoloniális hibriditások meghasadtságára emlékeztet a gyarmatosító logika hagyatékaként, amely az etnikai iden- 
titás „kialakulását” egy nem befejezett, teleologikus folyamatként értelmezve kívánta a maga részére kiaknázni. Tanulmányunkban rámutattunk arra, hogy a történelem folyamán (és manapság is) hiába próbálta egy külső erőcentrum kijátszani a moldáv identitás egy-egy számára kedvező rétegét a támogatott nacionalizmusok által, sikertelen volt mindegyik projekt, mert az identitáselemek között nincs alá-fölé rendeltség. Így „a kulturális reprodukció nem ugyanazt a végterméket eredményezi, hanem valami mást, a hibridet” (Bhabha 1994, 159.). Vagyis hiába próbált Oroszország, Románia vagy éppen az EU a keleti partnerségen keresztül adott kulturális irányvonalat érvényesíteni, a várakozásokkal szemben minden esetben egy sajátos helyi termék jött létre. Ez rendre megnyilvánul az ország (geo)politikai útkeresésében, ahogy Moldova újra és újra pufferzónában találja magát.

\section{Köszönetnyilvánítás}

A tanulmány a K 124291 számú, A poszt-szovjet után (?): A változó kelet-európai pufferzóna társadalmi folyamatainak földrajzi vizsgálata című projekt keretében, a Nemzeti Kutatási, Fejlesztési és Innovációs Hivatal (NKFIH) támogatásával készült.

\section{Irodalom}

Antonsich, M. (2009): National identities in the age of globalisation: The case of Western Europe. National Identities, 3., 281-299. http://doi.org/c4cj4d

Atlas DMR (2004): Atlas of the Dniester Moldavian Republic. Sheriff Publishing and Printing Center, Tiraspol

Benkö, A., Malek, M. (2005): Akteure des Konflikts um Transnistrien (Moldau). Südosteuropa, 1., 56-79.

Berg, L. D. (2004): Scaling knowledge: towards a critical geography of critical geographies. Geoforum, 5., 553-558. http://doi.org/bwc7s8

Belina, B.; Arambașa, M. (2007): Allägliche Identitätskonstruktionen in der Republik Moldau zwischen Rumänismus und Moldovenismus. Europa Regional, 4., 189-198.

Berindei, D. (1996): Die Kulturbeziehungen zwischen der Republik Moldova und Rumänien. Der Donauraum, 3-4. (Republik Moldova: Sonderheft), 103-106.

Berki M. (2017): A földrajzi lépték változó értelmezése és a cselekvőhálózat-elmélet. Földrajzi Közlemények, 3., 203-215.

Bhabha, H. K. (1994): The location of culture. Routledge, London

Bochmann, K., Dumbrava, V., Müller, D., Reinhardt, V. (Hrsg.) (2012): Die Republik Moldau (Republica Moldova) - Ein Handbuch. Universitätsverlag, Leipzig

Brenner, N. (1999): Beyond state-centrism? Space, territoriality, and geographical scale in globalization studies. Theory and Society, 1., 39-78. http://doi.org/bzw7j7

Brubaker, R. (1994): Nationhood and the national question in the Soviet Union and post-Soviet Eurasia: An institutionalist account. Theory and Society, 1., 47-78. http://doi.org/fnjpdk

Cazacu, M. (1996): Moldau - Bessarabien - Transnistrien. Der Donauraum, 3-4. (Republik Moldova: Sonderheft), 14-21. 
Cazacu, M., Trifon, N. (2017): Republica Moldova. Un stat în căutarea națiunii. Cartier, Chișinău

Chari, S., Verdery, K. (2009): Thinking between the posts: Postcolonialism, postsocialism, and ethnography after the Cold War. Comparative Studies in Society and History, 1., 6-34. http://doi.org/fkw97w

Cullen, D., Ryan, J., Winders, J. (2013): Postcolonialism. In: Johnson, N. C., Schein, R. H., Winders, J. (eds.): The Wiley-Blackwell companion to cultural geography. Wiley-Blackwell, Chichester, 508-523. http://doi.org/cwn6

Cusco, A. (2017): A contested borderland. Competing Russian and Romanian visions of Bessarabia in the late nineteenth and early twentieth century. Central European University Press, Budapest, New York

Dingsdale, A. (1999): New geographies of post-socialist Europe. The Geographical Journal, 2., 145-153. http://doi.org/cgfd53

Dumbrava, V. (2002): Die „Last der Geschichte” in der Republik Moldau. Südosteuropa, 7-9., 431-448.

Fukuyama, F. (2014): A történelem vége és az utolsó ember. Európa, Budapest

Goina, C. (2005): How the state shaped the nation: an essay on the making of the Romanian nation. Regio. Minorities, Politics, Society, 1.,154-169.

Gregory, D. (2004): The colonial present. Blackwell, Malden, Oxford, Carlton

Häkli, J. (2018): Afterword. Transcending scale. In: Herb, G. H., Kaplan, D. H. (eds.): Scaling identities. Nationalism and territoriality. Rowman \& Littlefield, Lanham, 271-282.

Hausleitner, M. (2008): Bessarabien als historische Region In: Khal, T., Metzeltin, M., Ungureanu, M. R. (Hrsg.): Rumänien. Raum und Bevölkerung, Geschichte und Geschichtsbilder, Kultur, Gesellschaft und Politik heute, Wirtschaft, Recht und Verfassung, historische Regionen. LIT Verlag, Berlin, Münster, Wien, Zürich, London, 825-839.

Heller, W., Arambașa, M. N. (Hrsg.) (2009): Am östlichen Rand der Euriopäischen Union - Geopolitische, ethnische und nationale sowie ökonomische und soziale Probleme und ihre Folgen für die Grenzraumbevölkeerung. Universitätsverlag Potsdam, Potsdam (Potsdamer Geographische Forschungen; 28.)

Hofbauer, H.; Roman, V. (1997): Bukowina, Bessarabien, Moldawien: Vergessenes Land zwischen Westeuropa, Rußland und der Türkei. Promedia Verlag, Wien

Illés T. (2018a): A kulturális globalizáció földrajzi vonásai. Tér és Társadalom, 2., 3-20. http://doi.org/cwn7

Illés T. (2018b): Kelet és Nyugat között - a román csoportok etnikai földrajzi vizsgálata a kezdetektől napjainkig. Földrajzi Közlemények, 2., 137-153.

Jones, K. T. (1998): Scale as epistemology. Political Geography, 1., 25-28. http://doi.org/c7pk6q

Kaplan, D. H. (2018): National identity and scalar processes. In: Herb, G. H., Kaplan, D. H. (eds.): Scaling identities. Nationalism and territoriality. Rowman \& Littlefield, Lanham, 31-47.

King, C. (2000): The Moldovans: Romania, Russia, and the Politics of culture. Hoover Institution Press, Stanford

Kiossev, A. (2011): The self-colonizing metaphor. Atlas of transformation. http://monumenttotrans formation.org/atlas-of-transformation/html/s/self-colonization/the-self-colonizing-meta phor-alexander-kiossev.html (Letöltés: 2018. október 3.)

Koobak, R., Marling, R. (2014): The decolonial challenge: Framing post-socialist Central and Eastern Europe within transnational feminist studies. European Journal of Women's Studies, 4., 330-343. http://doi.org/f239kr

Kovačević, N. (2008): Narrating post/communism. Colonial discourse and Europe's borderline civilization. Routledge, Abingdon http://doi.org/cwn8

Kőszegi M. (2016a): Nacionalizmusok Európa keleti felében. In: Bottlik Zs. (szerk.): Etnikai földrajzi kutatások Köztes-Európában. ELTE, Budapest, 35-43.

Kőszegi M. (2016b): Kis népek nacionalizmusa az európai posztszovjet térségben: a krími tatárok és a gagauzok. Földrajzi Közlemények, 4., 285-296.

Lazarus, N. (2012): Spectres haunting: Postcommunism and postcolonialism. Journal of Postcolonial Writing, 2., 117-129. http://doi.org/cwn9

Malešević, S. (2003): Researching social and ethnic identity: A sceptical view. Journal of Language and Politics, 2., 265-287. http://doi.org/frk2h5

March, L. (2007): From Moldovanism to Europeanization? Moldova's communists and nation building. Nationalities Papers, 4., 601-626. http://doi.org/cj34kb

Marciniak, K. (2009): Post-socialist hybrids. European Journal of Cultural Studies, 2., 173-190. http://doi.org/d85qhp 
Marston, S. A., Jones, J. P., Woodward, K. (2005): Human geography without scale. Transactions of the Institute of British Geographers, 4., 416-432. http://doi.org/dz5rcc

Biroul Național de Statistică (2004): Recensămîntul populației 2004, Culegere statistică. Vol. 1. Caracteristici demografice, naţionale, lingvistice, culturale. Biroul Național de Statistică, Chișinău

Biroul Național de Statistică (2014): Recensământul populației și al locuințelor din 2014. Biroul Național de Statistică, Chișinău. http://recensamant.statistica.md (Letöltés: 2018. október 3.)

Moore, D. C. (2006): Is the post- in postcolonial the post- in post-Soviet? Towards a global postcolonial critique. In: Kelertas, V. (ed.): Baltic postcolonialism. Rodopi, Amsterdam, New York, 11-43.

Neukirch, C. (1996): Die Republik Moldau: Nations- und Staatsbildung in Osteuropa. LIT Verlag, Münster (Osteuropa: Geschichte, Wirtschaft, Politik; 9.)

Neukirch, C. (2003): Moldau und Europa: Mehr als eine Nachbarschaft? Südosteuropa Mitteilungen, $4-5 ., 15-29$.

Nita, S. (2016): Circular migration within the EU-Moldova mobility partnership. In: Solé, C., Parella, S., Martí, T. S., Nita, S. (eds.): Impact of circular migration on human, political and civil rights. A global perspective. Springer, New York, 23-44. http://doi.org/cwpb

Oroszországi népszámlálás (1897): Pod red. N. A. Trojnickogo. t.II. Obshhij svod po Imperii rezul'tatov razrabotki dannyh Pervoj Vseobshhej perepisi naselenija, proizvedennoj 28 janvarja 1897 goda. Izdanie Central'nogo statisticheskogo komiteta Ministerstva vnutrennih del, S.-Peterburg, 1905. Tablica XIII. Raspredelenie naselenija po rodnomu jazyku.

Owczarzak, J. (2009): Introduction: Postcolonial studies and postsocialism in Eastern Europe. Focaal, 1., 3-19. http://doi.org/cjqhw2

Park, M. (2010): South reads Western and Eastern East: Second-hand orientalism in Kiltro, a Chilean martial arts film. In: López-Calvo, I. (ed.): One world periphery reads the other: Knowing the "oriental" in the Americas and the Iberian peninsula. Cambridge Scholars Publishing, Newcastle upon Tyne, 393-405.

Petrescu, C. (2001): Contrasting/conflicting identities. Bessarabians, Romanians, Moldovans. In: Trencsényi, B., Petrescu, D., Petrescu, C., Iordachi, C., Kántor, Z. (eds.): Nation-building and contested identities: Romanian and Hungarian case studies. Regio Books, Editura Polirom, Budapest, Iaşi, 153-179.

Račevskis, K. (2002): Toward a postcolonial perspective on the Baltic states. Journal of Baltic Studies, 1., 37-56. http://doi.org/dpg8k9

Radcliffe, S. A. (1997): Different heroes: Genealogies of postcolonial geographies. Environment and Planning D: Society and Space, 8., 1331-1333. http://doi.org/cwpc

Robinson, J. (2003): Postcolonializing geography: Tactics and pitfalls. Singapore Journal of Tropical Geography, 3., 273-289. http://doi.org/fnspp4

Said, E. (2000): Orientalizmus. Európa, Budapest

Sellier, A., Sellier, J. (1991): Atlas des peuples d'Europe centrale. La Découverte, Paris

Sharp, J. P. (2009): Geographies of postcolonialism. Spaces of power and representation. Sage, Los Angeles, London

Sidaway, J. D., Woon, C. Y., Jacobs, J. M. (2014): Planetary postcolonialism. Singapore Journal of Tropical Geography, 1., 4-21. http://doi.org/f54s67

Sieg, H. M. (2011): Der Transnistrien-Konflikt: Voraussetzungen für eine Konfliktlösung. Südosteuropa Mitteilungen, 3., 63-77.

Siupur, E. (1993): Von Bessarabien zur Republik Moldau - die historischen Wurzeln eines Konflikts. Südosteuropa, 3-4., 153-162.

Solomon, F. (2002): Auf der Suche nach Identität: Ethno-kulturelle Auseinandersetzungen in der Republik Moldau. Südosteuropa, 7-9., 449-464.

Stenning, A., Hörschelmann, K. (2008): History, geography and difference in the post-socialist world: Or, do we still need post-socialism? Antipode, 2., 312-335. http://doi.org/d8h63b

Suchland, J. (2011): Is postsocialism transnational? Signs: Journal of Women in Culture and Society, 4., 837-862. http://doi.org/c6cwq3

Țîcu, O. (2018): Homo Moldovanus Sovietic. Teorii și practici de construcție identitară în R(A)SSM (1924-1989). Arc, Chișinău

Timár J. (2006): Nyugati hegemónia a földrajzban. In: Kiss A., Mezősi G., Sümeghy Z. (szerk.): Táj, környezet és társadalom: ünnepi tanulmányok Keveiné Bárány Ilona professzor asszony tiszteletére. 
SZTE Éghajlattani és Tájföldrajzi Tanszék; SZTE Természeti Földrajzi és Geoinformatikai Tanszék, Szeged, 707-716.

Tlostanova, M. (2012): Postsocialist $\neq$ postcolonial? On post-Soviet imaginary and global coloniality. Journal of Postcolonial Writing, 2., 130-142. http://doi.org/f3tfkm

Todorova, M. (2010): Balkanism and postcolonialism, or on the beauty of the airplane view. In: Bradatan, C., Oushakine, S. A. (eds.): In Marx's shadow. Knowledge, power, and intellectuals in Eastern Europe and Russia. Lexington Books, Lanham. 175-195.

Tontsch, G. H. (1996): Der verlorene Sohn: Moldova und Rumänien. Südosteuropa Mitteilungen, 4., 336-343.

Tőkés R. (1998): Iránytű vagy zsákutca? - A legújabb tranzitológiai irodalommal vitázva. Beszélő, 2., 31-38.

Tuvikene, T. (2016): Strategies for comparative urbanism: Post-socialism as a de-territorialized concept. International Journal of Urban and Regional Research, 1., 132-146. http://doi.org/f8wj3b

van Meurs, W. (2003): Moldova - nationale Identität als politisches Programm. Südosteuropa Mitteilungen, 4-5., 31-43.

Verdery, K. (1996): Nationalism, postsocialism, and space in Eastern Europe. Social Research, 1., 77-95.

Wolff, L. (1994): Inventing Eastern Europe. The map of civilization on the mind of the Enlightenment. Stanford University Press, Stanford

Zabarah, D. A. (2013): Die Republik Moldau: Staatswerdung im Spannungsfeld zwischen historischen Ansprüchen und dem Zerfall alter Ordnungen. In.: Hilger, A., von Wrochem, O. (Hrsg.): Die geteilte Nation: nationale Verluste und Identitäten im 20. Jahrhundert. Oldenburg Verlag, München 117-134. http://doi.org/cwpd 